FINLAND, M., COLLINS, H. S., GOCKE, T. M., and WELLS, E. B. (1949), Ann. intern. Med., 31, 39.

FINLAND, M., COLLINS, H. S., and PAINE, T. F. (jun.), (1948), 7. Amer. med. Ass., 138, 946.

GOCKE, T. M., COLLINS, H. S., and FINLAND, M. (1949), Arch. intern. Med., 84, 857.

GRATER, W. C., and RIDER, J. A. (1949), Tex. St. F. Med., 45, 568.

HARNED, B. K., CUNNINGHAM, R. W., CLARK, M. C., COSGROVE, R., HINE, C. H., McCAULEY, W. J., STOKEY, E., VESSEY, R. E., YUDA, N. N., and SUBBA ROW, Y. (1948) Ann N. Y. Acad. Sci. 51 , I82.

HARVEY, J. C., MIRICK, G. S., and SČHẢUB, I. G. (1949), F. clin. Invest., 28, 987 .

HERRELL, W. E., and HEILMAN, F. R. (1949), Proc. Mayo Clin., 24, I 57 .

KIERLAND, R. R., HERRELL, W. E., and O'LEARY, P. A. (1950), Arch. Derm. Syph., N.Y., 61, 185.

KNEELAND, Y. (jun.), ROSE, H.'M., and GIBSON, C. D. (1949), Amer. F. Med., 6, 41.

KNIGHT, V., RUIZ-SANCHEZ, F., RUIZ-SANCHEZ, A., and McDERMOTT, W. (1949), Amer. $\mathcal{F}$. Med., 6, $4^{\circ} 7$.

LENNETTE, E. H., MÉIKLEJOHN, G., and THELEN, H. M. (1948), Ann. N.Y. Acad. Sci., 51, 331.

LOGAN, M. A., ME'TZGER, W., I., WRIGHT, L. T., PRIGOT, A., and ROBINSON, E. A. (I950), Amer. $\mathcal{F}$. Surg., 79, 229.

LONG, P. H., CHANDLER, C. A.,' BLISS, E. A., BRYER, M.' S., and SCHOENBACH, E. B. (I949), $\mathcal{f}$. Amer. med. Ass., 14I, 315 .

LYNAS, M. A. (1950), Lancet, 1 , 373.

MCVAY, L. V., LAIRD, R. L., and SPRUNT, D. H. (1949), Science, ro9, 590.

MARKS, J. A., WRIGHT, L. T., and STRAX, S. (1949), Amer.

MEIKLEJOHN, G., and SHRAGG, R. I. (1949), f. Amer. med. Ass., 140, 391.

NICHOLLS, D. R., and NEEDHAM, G. M. (1949), Proc. Mayo Clin. 24, 300.

OLSHAKER, B., ROSS, S., RECINOS, A. (jun.), and TWIBLE,

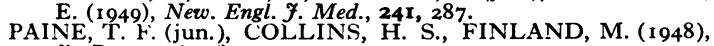
F. Bact., 56, 489 .
PRICE, C. W., RANDALL, W. A., and WELCH, H. (IS48), Ann. N.Y."Acad. Sci., 5I, $21 \mathrm{I}$.

ROSE, H. M., and KNEELAND, Y. (1949), Amer. F. Med., 7, 532. ROSS, S., SCHOENBACH, E. B., BURKE, F. G., BRYER, ¿ M. S., RICE, E. C., and WASHINGTON, J. A. (I948), 7. Amer, med. Ass., 138, I213.

RUTENBERG, A. M., and SCHWEINBURG, F. B. (1949), New Engl. F. Med., 241, 698.

SCHOENBACH, E. B. (1949), f. Amer. med. Ass., 139, 450.

SCHOENBACH, E. B., and BRYER, M. S. (1949), f. Amer. med.

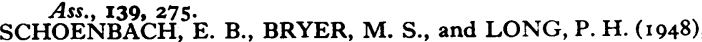
Ann. N.Y. Acad. Sci., 51, 267.

SCHWACHMAN, H., CROCKER, A. C., FOLEY, G. E., and PATTERSON, P. R. (1949), New Engl. F. Med., 241, 185. SPINK, W. W., BRAUDE, A., CASTANEDA, M. R., and GOYTIA, R. S. (1948), f. Amer. med. Ass., 138, I 445. SPINK, W. W., and YOW, E. M. (1949), F. Amer. med. Ass., 14I,

STEENKEN, W., and WOLINSKY, E. (1949), Amer. Rev. Tuberc.,

STEINB, 22I. A.S. (1949), Amer. Rev. Tuberc., 59, 624.

THOMPSON, B. F. (jun.), and SPECTOR, S. (1949), f. Pediat.

WH, 546. C. H. (1950), Lancet, 1,139 ,

WHITTLE, C. H. (1950), Lancet, I, 139,
WILLCOX, R. R. (1949), Brit. med. F., 2, 1076.

W. WONG, S. C., and COX, H. R. (1948), Ann. N.Y. Acad. Sci., 5I, 290 .

T. (1949) Ann. intern. Med., 31, 53.

WOODWARD, T. E. RABY, W. T., EPPES, W., HOLBROOK, W. A., and HIGHTOWER, J. A. (1949), F. Amer. med. Ass.,

$139,830$.
WRIGHT, L. T., METZGER, W. I., SHAPERO, E. B., CARTER, ב S. J., SCHREIBER, H., and PARKER, J. W. (I949), Amer.

W. Surg., 78, 15. A., and HILL, L. M. (1948), F. Amer. med. Ass., 138, 408

\title{
PRIMARY OR ESSENTIAL HYPERIDROSIS
}

\author{
By Professor A. M. Boyd, F.R.C.S., and R. P. Jepson, F.R.C.S. \\ The Professorial Department of Surgery, The Royal Infirmary, Manchester
}

Primary hyperidrosis may be defined as excessive sweating of unknown aetiology. It is a diagnosis of exclusion for although this condition has many characteristic features and can usually be diagnosed from the history alone, secondary and thermoregulatory sweating must first be eliminated. Thermoregulatory sweating occurs mainly on the body and is a physiological mechanism designed to maintain the body temperature within a narrow range. Its features are so distinctive that there are no difficulties in diagnosis. Secondary hyperidrosis is a symptom of a local or general cause. Thus it may follow, for example, central nervous system disease, an irritative peripheral nerve lesion, toxic states or even a glomus tumour. It is unusual for it to have the strictly symmetrical distribution of primary hyperidrosis, and the presence of a causative lesion establishes the diagnosis (Wright, 1948).

The following is a typical case of primary hyperidrosis:

Patient A.H., male, aged 19 years. Occupation: Hotel trainee.

The patient developed normally until the age of $N$ eight when he began to sweat excessively on the $N$ palms and soles of the feet. The dorsum of the N hands and feet, face and body continued to sweat $\omega$ normally. The axillae were affected by the hyperidrosis but to a much milder degree. The sweating was not affected by climatic conditions, $\stackrel{\oplus}{\oplus}$ and was as excessive in winter as in summer. The hyperidrosis was precipitated by varying stimuli, but particularly writing and driving a car. Embarrassment and strange company acted to a less 
Fuly 1950

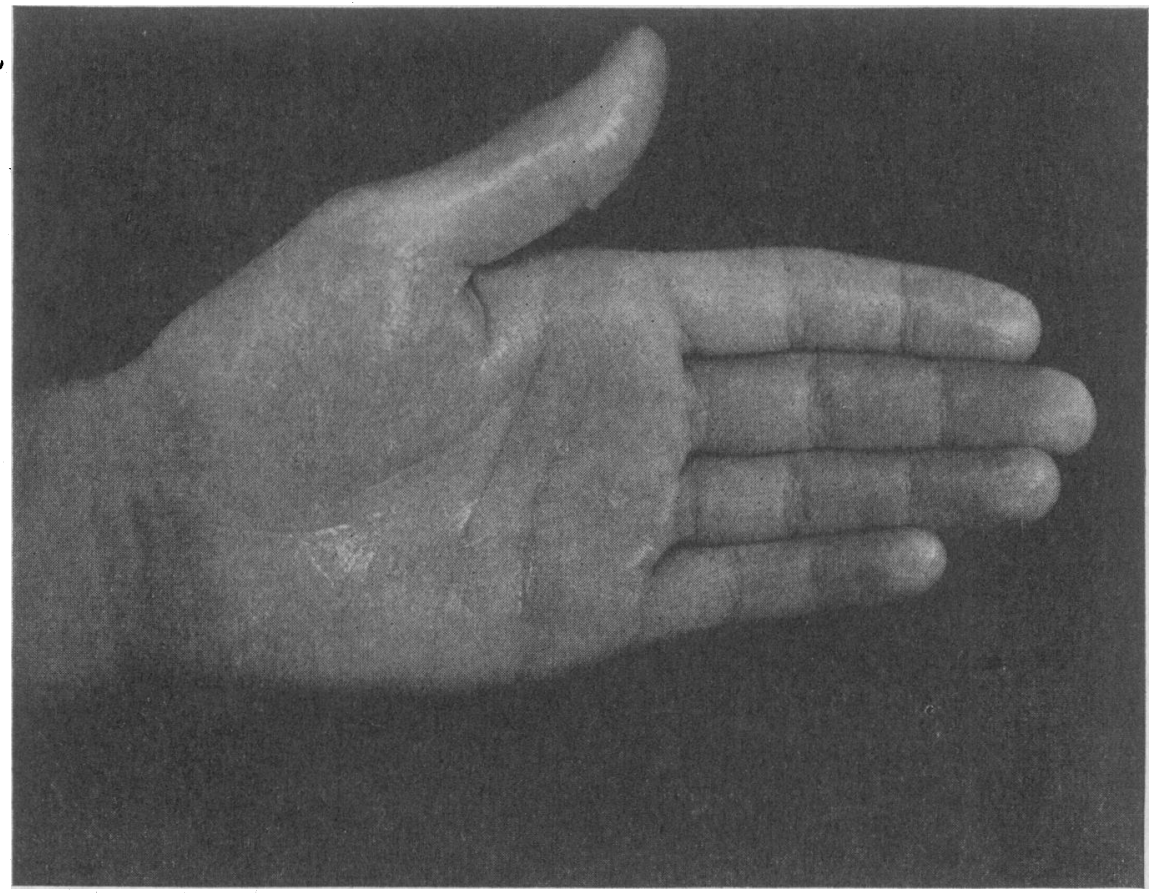

Fig. I.
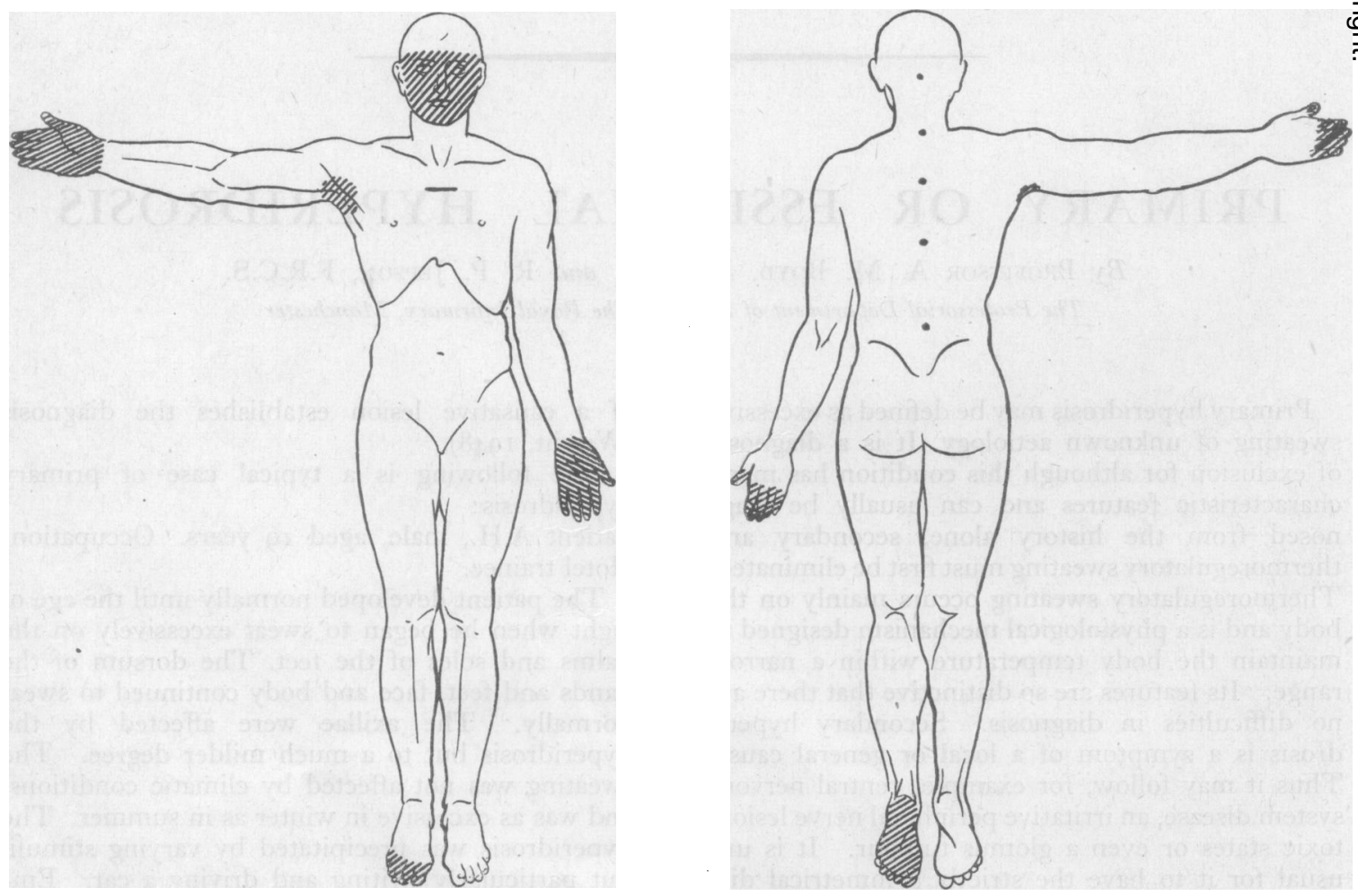

Fig. rb.

FIG. Ia. 
TABLE 1

\begin{tabular}{|c|c|c|c|c|c|c|}
\hline Name & Sex & Age & Site & $\begin{array}{l}\text { Length of } \\
\text { History }\end{array}$ & Associated Factors & $\begin{array}{l}\text { Raynaud's } \\
\text { Phenomenon }\end{array}$ \\
\hline $\begin{array}{l}\text { H.B. } \\
\text { R.A. } \\
\text { R.D. } \\
\text { E.D. } \\
\text { J.M. } \\
\text { S.W. }\end{array}$ & $\begin{array}{l}\text { F. } \\
\mathbf{M} . \\
\mathbf{M} . \\
\mathbf{M} . \\
\mathbf{M} .\end{array}$ & $\begin{array}{l}47 \\
23 \\
19 \\
25 \\
26 \\
38\end{array}$ & $\begin{array}{c}\text { Hemi-facial } \\
\text { Hands } \\
\text { Hands and feet } \\
\text { Feet } \\
\text { Hands } \\
\text { Hands and feet }\end{array}$ & $\begin{array}{r}1 \text { year } \\
18 \text { years } \\
5 \text { years } \\
18 \text { years } \\
4 \text { years } \\
12 \text { years }\end{array}$ & $\begin{array}{c}\text { Sinusitis } \\
\text { Neurotic traits } \\
\text { Neurotic traits } \\
\text { - } \\
\begin{array}{c}\text { Neurotic traits (son also de- } \\
\text { veloped hyperidrosis) }\end{array}\end{array}$ & $\begin{array}{l}\bar{z} \\
\bar{z} \\
+\overline{\text { mild }} \\
\bar{z}\end{array}$ \\
\hline $\begin{array}{l}\text { P.M. } \\
\text { N.J. } \\
\text { F.R. } \\
\text { A.H. } \\
\text { T.T. } \\
\text { B.N. } \\
\text { F.L. } \\
\text { B.W. } \\
\text { F.B. }\end{array}$ & $\begin{array}{l}\text { M. } \\
\text { M. } \\
\text { M. } \\
\text { M. } \\
\text { M. } \\
\text { M. } \\
\text { M. } \\
\text { M. } \\
\text { F. }\end{array}$ & $\begin{array}{l}20 \\
27 \\
48 \\
19 \\
19 \\
20 \\
38 \\
22 \\
10\end{array}$ & $\begin{array}{c}\text { Hands } \\
\text { Feet } \\
\text { Feet and hands } \\
\text { Hands, axilla and feet } \\
\text { Hands } \\
\text { Hands and feet } \\
\text { Hands and feet } \\
\text { Hands and feet } \\
\text { Hands }\end{array}$ & $\begin{array}{l}\text { 10 years } \\
3 \text { years } \\
20 \text { years } \\
11 \text { years } \\
5 \text { years } \\
\text { From birth } \\
\text { From birth } \\
\text { From birth } \\
\text { From birth }\end{array}$ & $\begin{array}{c}\text { Neurotic traits } \\
\text { - } \\
\text { Neurotic traits } \\
\text { Gustatory sweating } \\
\text { - } \\
=\end{array}$ & $\begin{array}{c}\overline{-} \\
+\overline{\text { mild }} \\
\text { Acrocyanosis } \\
\text { Mild acrocyanosis } \\
\text { - }\end{array}$ \\
\hline
\end{tabular}

extent. Food and drink had no effect and the extremities were always dry on first awakening in the morning. The bursts of hyperidrosis usually lasted for minutes or hours and were unaccompanied by any vasomotor phenomena. His hands were normally warm and there was no history of Raynaud's phenomena or pain in the arm. His general health had always been excellent. The degree of sweating was quite surprising. The hands literally dripped with sweat (Fig. I) and his shoes had to be emptied at intervals. It became impossible to write a letter or do any fine pen work such as ledger keeping. Socks and shoes were quickly rotted. Psychologically, he was a well-balanced individual. Social life and personal contact which was necessary in his occupation were made difficult by the hyperidrosis. No local or general abnormality was found on examination, except for the sweating already referred to. Sympathectomy completely relieved the excessive hand sweating.

\section{Clinical Picture}

The sweating in patients with primary hyperidrosis is typically symmetrical and 'emotional' or 'mental' in distribution. The palms are usually most affected whilst the axillae, feet and face are involved to a lesser degree (Figs. Ia, Ib). Occasionally only one part, for example the feet, sweats excessively, but more often all are involved with one area predominating.

On awakening in the morning the affected area is always dry. Early after rising it becomes persistently moist, with attacks lasting for minutes or hours, in which the involved skin literally runs with perspiration. These characteristic bursts of excessive sweating are frequently fired off by ex- citement, embarrassment or by a physical act demanding mental concentration, such as driving a 을 car or writing. Often, however, the patient states that the attacks begin and end for no apparent $\subseteq$ reason, being equally severe in winter as in summer. Exercise alone rarely causes anything $\vec{\oplus}$ beyond normal thermoregulatory sweating. may be impossible for the patient to write more than a line of a letter before the paper becomes soaked with perspiration. This is a serious educational and economic handicap to school children, students or clerks who are compelled to write protected by several sheets of blotting paper. Otherwise the patient is perfectly healthy. Associated Raynaud's phenomena or a mild acrocyanosis are not uncommon but probably the incidence is not greater than on the population as a whole. The clammy cold extremities so common in patients with acrocyanosis or hypersympathotonia (Veal and Shadid, 1949), where evaporation is minimal, are entirely different in the degree of perspiration, and they never show the explosive bursts of sweating so characteristic of primary hyperidrosis.

Sixteen patients with severe primary hyperidrosis have been operated upon in the last three years on the Professorial Surgical Unit of the Manchester Royal Infirmary. Their case histories N are briefly summarized in Table I. Certain facts $N$ are striking. If one atypical case with unilateral facial sweating is excluded, the onset of the hyperidrosis was always before the age of 24 years, the majority occurring at birth or in young adult life. Three patients were females, 13 males. The pre- $\stackrel{0}{?}$ ponderance of males is in general agreement with 0 previously published figures. In only one case could a family history be obtained (S.W.). This patient's son, aged ${ }_{5}$, had suffered from palmar 
hyperidrosis since birth. None of S.W.'s other five children were affected.

It is important to know something of the natural history of primary hyperidrosis, for if it is a remitting disease, temporization alone would lead to cure. Unfortunately, as far as one can tell, once established the condition remains or progresses. No case has occurred in our experience, nor has a case been discovered in the literature of a spontaneous cure. Changes of occupation or environment may, however, cause a temforary remission of the severer symptoms. This may occur most unexpectedly, as in case E.P., who experienced far less trouble with hyperidrosis during his war-time Army service in the tropics. The condition retrogressed, however, to its previous severity on the patient's return to civilian life.

The psychological make-up of the patients in these cases was investigated with care. Although some were perfectly well adjusted people, many showed neurotic traits. It is doubtful, however, if the hyperidrosis was caused or aggravated by the neurosis. It seems more likely that the unpleasant features of the hyperidrosis had caused the patient to withdraw from social activities and become introspective. The sweating had without doubt magnified, if it had not initiated many of the neurotic traits seen amongst this group.

\section{Aetiology}

By definition, a patient with primary hyperidrosis is one in whom no local or general cause for the condition can be found. Nevertheless, many suggestions as to its causation have been made. Histology (Adson, Craig and Brown, 1935) has failed to show either numerical or structural differences from the normal sweat pattern. It is also known (Gurney and Bunnell, 1942) that 'biopsy of the skin in regions to which the sympathetic nerves have been severed failed to show any alteration from the appearance of the glands in normal regions to which the sympathetic nerve 'supply was intact.' A sympathectomy will, nevertheless, permanently cure the primary hyperidrosis, in contrast to the great tendency to relapse in Raynaud's phenomenon where the important lesion is the 'local fault.' The histological examination of the sympathetic ganglia and chains removed in our patients have not shown any abnormality. Wertheimer and Barrie (1947) claim, however, to have found abnormal collagen sclerosis and degeneration in excised ganglionic tissue. Their histological examination followed previous novocaine injections and this may have contributed to the final histological picture. Leslie-Roberts (1934) suggested that the hyperidrosis was due to the "abnormal function of dermal mesenchymal cells.' This has never been confirmed.

In summary, there is no evidence of a 'local anatomical fault' in either swest glands or sympathetic nervous system in patients with primary hyperidrosis.

It is theoretically possible that the sweat glands of the hyperidrotic areas are abnormally sensitive to locally released chemicals of the acetyl-choline group. Several of our patients were tested before and after operation with pilocarpine, mecholyl and furmethide. They responded just as normal people both in intensity and distribution of sweating.

It is well known that sweat dysfunction can follow a wide range of organic central nervous system disorders, such as encephalitis, hypothalamic lesions or spinal cord irritation. Telford (1942) has described two cases cured by removal of a cervical rib. No neurological lesion was demonstrated in our cases nor has it developed in other cases followed up for longer periods (Haxton, 1948). Neverthless, although there is no evidence of organic nervous disease, there is much to suggest that the abnormal sweating is due to a central out-flow possibly from the hypothalamic region. During times of central suppression, such as in sleep or under pentothal narcosis, the sweating is in abeyance. Patients state that their hands are always dry on awakening in the morning. 'In one case pentothal was administered during a severe bout of hyperidrosis. This caused an abrupt cessation of sweating. Conversely, stimuli which invoke mental tenseness or stress cause excessive perspiration. Sanctorius ( 1720 ) wrote 'a body which is at rest while the mind is intensely agitated has a stronger perspiration and less weight than a body that is strongly moved whilst the mind is at rest.' It has been suggested that primary hyperidrosis is a true psychomatic disorder where a mental or emotional conflict is translated into a physical defect. Against this is the very early onset of some cases. Three patients could not remember when they were free from hyperidrosis, and in none of our cases could the onset of sweating be attributed by the patient to any one psychological experience. It is also claimed (Adson, Craig and Brown, 1935) that such symptoms as abnormal fatigue, vasomotor instability and gastrointestinal functional disorders are commonly associated with hyperidrosis. We have not found this to be so, although it is evident that any neurotic tendencies will be exaggerated by a complaint which renders normal social and professional life intolerable.

\section{Complications of Hyperidrosis}

The psychological stress under which the patient 


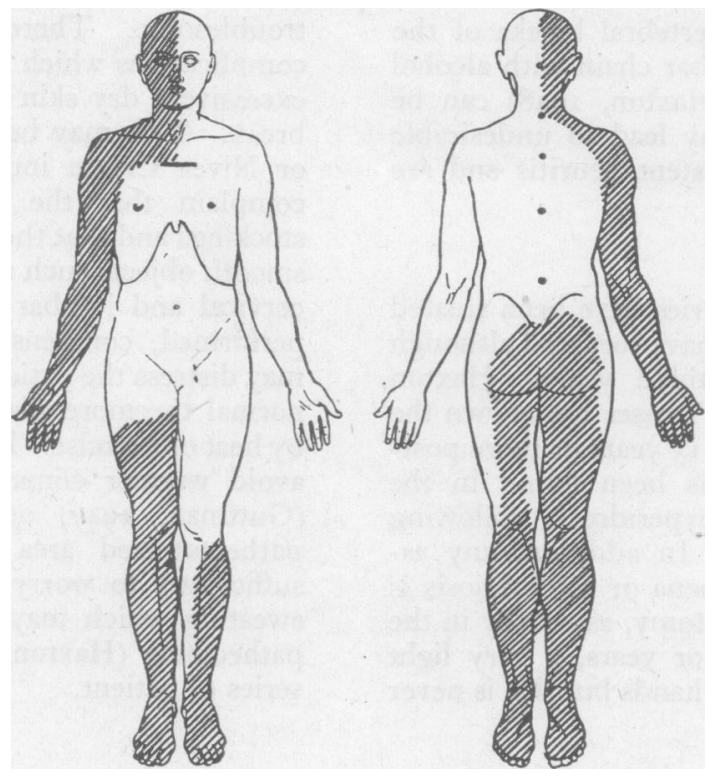

FIG. 2.

labours has already been mentioned. In addition, local complications may arise in the hyperidrotic areas. Interdigital and plantar infections are especially common in the feet. These are often fungoid in origin, with a secondary pyogenic bacterial infection, leading to recurrent lymphangitis and cellulitis. Most of our cases have been referred for sympathectomy by dermatologists, because the sweating has resisted all local measures. Rashes, vesicle formation and dyshydroses are common on the hands. The feet become particularly tender, soft and macerated in the hot weather and through pain or bleeding, may greatly limit the patient's walking. Axillary sweating is often malodorous. Socks and shoes are quickly rotted by the sweating and renewals may be an economical imposition in the lower income groups.

\section{Treatment}

In the treatment of patients with severe hyperidrosis, measures designed to damage the sweat glands, such as radiation, formalin or alum applications, do not cure, rarely alleviate and often cause considerable damage to the skin. Occasional cases have been reported cured by novocaine infiltration of the sympathetic chain (Mandl, 1947) or peri-arterial stripping (LeClerc and Berger, 1947). These are theoretically uncertain methods for permanent relief and we have no experience in their use.

For hand sweating the second and third thoracic ganglia and intervening chain should be resected.
This dries the hand, the arm and the axilla (Fig. 2), and because the stellate ganglion is spared, avoids the unsightly and sometimes troublesome complications of a Horner's syndrome. The anterior supra-clavicular approach to the chain (Telford, 1942) is most satisfactory. It gives a ? fine cosmetic result and is not so traumatic as the posterior rib-resection exposure which is so often followed by a good deal of aching and an ugly scar. Both sides may be done at the same operation and the patient discharged from hospital within five days. If facial sweating is present then the stellate ganglion must be excised, preferably together with the second and third thoracic ganglia.

For the lower limb 2 in. of lumbar chain together with two lumbar ganglia should be excised opposite the third lumbar vertebra, through an extra-peritoneal loin incision. This completely dries the troublesome foot sweating and a varying area on the remainder of the leg (Fig. 2). Both sides may be completed at the same operation; the convalescence is characteristically uneventful and the patient is discharged on the eighth postoperative day. The highest lumbar ganglion lying beneath the crus of the diaphragm is not resected as its fibres probably only supply the upper thigh. Bilateral removal of the highest lumbar ganglion has also been condemned because of its possible effect on ejaculation in the male. A review of many other cases in which the highest lumbar ganglion has been resected on both sides does not support this view (Rose). If operation is contra- 
indicated or refused, paravertebral blocks of the stellate ganglion or the lumbar chain with alcohol (White, 1940) or phenol (Haxton, 1948) can be used. These, however, may lead to undesirable side effects such as a persistent neuritis and are probably better avoided.

\section{Results}

All the patients in this series have been treated by sympathectomy. None have recurred although the longest follow-up is three years. Haxton (1948) reporting on Telford's cases has shown the cure to be permanent up to 15 years or more postoperatively. No report has been found in the literature of relapse of hyperidrosis following adequate sympathectomy. In addition, any associated Raynaud's phenomena or acrocyanosis is improved by the sympathectomy, especially in the feet. After some months or years, a very light moisture may return on the hands but this is never troublesome. There are, however, some minor complications which follow sympathectomy. The excessively dry skin of the hands may crack and break. This may be relieved by regular lanoline or Nivea Cream inunctions. Women especially complain that the dry finger-skin catches in stockings and that the fingers are too dry to handle smooth objects such as playing cards. When both cervical and lumbar sympathectomies have been performed, compensatory sweating on the body may distress the patient. This is an aggravation of normal thermoregulatory sweating being invoked by heat or exercise. Probably these patients should avoid warmer climates. Peri-lesionary sweating (Guttman, 1947) on the fringe of the sympathectomized area may occur, though rarely sufficiently to worry the patient. The gustatory sweating which may follow an upper limb sympathectomy (Haxton, 1948) was not seen in this series of patient.

\section{BIBLIOGRAPHY}

ADSON, A. W. CRAIG, W. McK., BROWN, G. E. (1935), Arch. Surg. Chicago, 3I, 794.

GURNEY, R., BUNNELL, I. L. (1942), f. Clin. Investigation, 21, 260.

GUTTMAN, L. (1947), Postgrad. Med. f., 23, 353.

HAXTON, H. A. (1948), Brit. Med, $\mathcal{F}_{\text {., }}$ 1, 636.

HAXTON, H. A. (1948), Brain, 71, 16.

LECLERC, F. P., and BERGER (1947), Mémoires de L'Académie de Chirurgie, 73, 105.

LESLIE-ROBERTS, H. (1934), Brit. F. Derm. Syph., 46, 126.
MANDL, F. (1947), 'Paravertebral Block,' W. Heinemann Ltd., London, pp. 297.

ROSE, S. S. Personal Communication.

SANCTORIUS (1720), 'Médicina Statica Edz.,' trans. Johm Quinsy, London, W. \& J. Newton, 344 .

TELFORD, E. D. (1942), Brit. Med. Y., 2, 96.

VEAL J. R. SHADID, J. N. (1949), Surgery, 26, 89

WERT'HEIMER, P., BẢRIE, (1949), Surrery, 26, 89.

WHITE, J. C. (1940), Surg. Gynec. Obstet., 71, 334.

WRIGHT, A. D. (1948), 'British Surgical Practice,' Butterworth \& Co., London, 5, 6r. 